\title{
Latrine coverage and its utilisation in a rural village of Eastern Nepal: a community-based cross-sectional study
}

\author{
Shyam Sundar Budhathoki ', Gambhir Shrestha, Meika Bhattachan, Suman Bahadur Singh, Nilambar Jha \\ and Paras K. Pokharel
}

\begin{abstract}
Background: A little more than 1/3rd of the rural households in Nepal have improved latrine facility. The government of Nepal is working towards making an open defecation free area all over Nepal. There is no data found in literature searches regarding the status of latrines and its utilisation in Nepal. This study aims to estimate the coverage and utilisation of latrine and its associated factors in a rural community of Nepal.
\end{abstract}

Methods: We conducted a cross sectional study in March 2015-September 2015 among 625 households in Hattimuda Village, Morang district in Eastern Nepal using semi-structured pre-tested questionnaire with observational checklists.

Results: Out of 623 households, 473 (76.9\%) have latrine facilities. There is an increase in latrine coverage in Hattimuda by $37 \%$ (38.9\% in 2011 to $75.9 \%$ in 2016). Majority of the latrines (89.9\%) were functional, however 32.3\% needs maintenance. The extent of latrine utilisation among those households with a toilet at home was satisfactory (94.3\%). Presence of child below 5 years of age at home (OR 2.37, 95\% Cl 0.05-0.46), functional latrine (OR 27.37, 95\% $\mathrm{Cl}$ 6.84-109.45), frequency of cleaning (OR 3.66, 95\% Cl 1.09-12.29) and latrine constructed with self-initiation (OR $4.21,95 \% \mathrm{Cl} 1.06-16.66)$ are factors significantly associated with the utilisation of the latrine.

Conclusions: While the coverage needs to be increased, appropriate interventions to increase the utilisation of latrine needs to be in place so that the village moves closer to open defecation free (ODF) status. As other studies are not found from Nepal, the findings from this study can be used a reference for other rural areas of Nepal.

Keywords: Latrine coverage, Open field defecation, Open defecation free initiative, Sanitation in rural Nepal

\section{Background}

Worldwide, the disease burden associated with poor water, sanitation, and hygiene is estimated to account for $4.0 \%$ of all deaths and $5.7 \%$ of the total disease burden in disability-adjusted life year. These deaths occur principally due to diarrhoeal diseases, schistosomiasis, trachoma, ascariasis, trichuriasis, and hookworm infection [1,2]. Diarrhoea accounts for the largest share of sanitation-related morbidity and mortality, causing an estimated 1.4 million deaths annually [3].

*Correspondence: ss.budhathoki@gmail.com

School of Public Health and Community Medicine,

B.P. Koirala Institute of Health Sciences, Dharan, Nepal
More than 2.5 billion people in the world are still lacking access to improved sanitation and more than half of these people reside in low and middle-income countries. Globally, about $15 \%$ of the population still practice open defecation [4]. An estimated 1.1 billion people practice open defecation, exposing themselves and the community to major health risks $[4,5]$.

Having a latrine at home is found to be a protective factor for communicable diseases $[6,7]$. About $52 \%$ of the population practice proper utilisation of latrine in low income countries $[8,9]$. Improper utilisation of sanitary facilities leads to the contamination of the water sources. Proper utilisation of sanitary facilities helps to interrupt diseases transmitted through the faecal-oral route [10]. 
Efforts to increase access to safe water and improved latrine thus help to promote the proper utilisation of sanitary facilities [11]. An example of such efforts can be seen in neighbouring- India "Take Poo to the Loo" campaign, which seeks to drive nationwide change by influencing public opinion to call for an end to open defecation in India [12].

\section{Sanitation situation in Nepal}

In Nepal, improper sanitation is a major cause of diarrhoea [13]. According to Nepal Demographic Health Survey 2011 report, $38 \%$ of households have improved toilet facility, 53\% urban and 36\% rural households. The majority of households, $43 \%$ (48\% rural and $11 \%$ urban) use non-improved latrine facilities. About $36 \%$ of the households still use a bush or open field for defecation [14].

Presence of improved latrine in the household is associated with safe disposal practices for child faeces [15]. Majority of the population in rural areas practice open defecation. Improvement in the sanitary habit of the people is essential for overall improvement in health status of the people. Both coverage and the use of latrine are essential for the health benefit of the community associated with improved sanitation [16].

\section{Sanitation initiatives in Nepal}

Sanitation improvement programs in combination with water supply projects began in 1990s in Nepal. The programs expanded over the years with different non-governmental agencies supporting the sanitation improvement activities to increase toilet coverage. Community Led Total Sanitation (CLTS), which began in 2003 and School Led Total Sanitation (SLTS) in 2006 are approaches that emphasized on creating open defecation free (ODF) communities in Nepal. This ODF approach became popular over time with Nepal declaring its first ODF village (Ghachok) in 2007 and district (Kaski) in 2011 [17]. The Sanitation and Hygiene masterplan 2011 has highlighted ODF approach as a priority sanitation initiative [17]. Government of Nepal is committed to making Nepal open defecation free (ODF) by 2017. This initiative targets to bring down the faecal-oral transmission of diseases in Nepal [18]. In order to reach the country wide ODF status, the sanitation and hygiene master plan 2011 of Nepal aims for all households in Nepal to have access to toilet by 2017 [17].

There are very few studies found in Nepal that report on the status and utilisation of latrines, especially in Eastern Nepal. Therefore, we conducted this cross sectional study to assess the utilisation of latrine in a rural community. The study aims to estimate the coverage and utilisation of latrine in Hattimuda village and to examine the factors associated with the utilisation of latrines.

\section{Methods}

\section{Study setting and design}

We conducted a community-based cross-sectional study in Hattimuda village, Morang district, Eastern Nepal from March 2015 to September 2015. We chose Hattimuda village purposively, as it is the nearest village to the Comprehensive Health Service Area, a community hospital in the rural field practice area of School of Public Health and Community Medicine, B P Koirala Institute of Health Sciences, Dharan, Nepal. Community medicine teaching and learning activities for undergraduate and postgraduate medical students takes place in the rural field practice area covered by the hospital. The local government is working towards declaring Hattimuda village as an open defecation free village. Therefore, the findings of the study could also provide evidence to the government to assist Hattimuda reach the open defecation status. We chose the village so that we can use the findings from the study to design community led activities for hygiene promotion. The purpose was also to be able to longitudinally follow-up the interventions and measure the impact of our community based activities. We conducted this study prior to starting our community based teaching and learning activities in Hattimuda, so this study can also provide a baseline information on latrine utilisation for Hattimuda village.

\section{Sanitation situation in Hattimuda}

Hattimuda village occupies the total area of $13.56 \mathrm{~km}^{2}$. According to National Housing and Population Census 2011 , the population of the village is 10,250 of which 5141 are males and 5109 are females. In 2011, the total number of households in the area is 2206 of which only $38.9 \%$ have the toilet facility [16]. Following the national campaign, Hattimuda has also the target to attain open defecation free status by 2017. The activities by local government for sanitation are: formation of sanitation sub-committees in the villages, fortnightly door-to-door campaigns to educate the households regarding latrine construction and its use, disseminate sanitary awareness message through community groups (school teachers' group, mothers' group, students' network and health volunteers' groups), and material support to the socio-economically marginalized households to construct toilets [19].

\section{Sample size}

In National Population and Housing Census 2011, the percentage of households with toilet facility in Hattimuda village was $38.9 \%$ [16]. By using a single population proportion formula considering the coverage of latrine as 38.9 at $95 \%$ confidence interval and relative precision of $10 \%$, the required sample size was 625 households. 


\section{Sampling technique}

Out of the 9 wards in Hattimuda village, 5 wards were chosen randomly using lottery method (Additional file 1). We selected every second house for an interview until sample size was reached proportionate to population size in the respective wards.

\section{Data collection}

We collected the data by face-to-face interviews using pretested semi-structured questionnaires, which included socio-demographic characteristics of the household, status of the latrine, its utilisation, sanitary behaviour and an observation checklist for latrine. Latrine utilisation was assessed by asking if all family members above 5 years use latrines or not. We assumed that people above 5 years should be able to use the latrine, hence 5 years cut off value was taken. One family member above 16 years of age, preferably head of the household was included in the study. Family who have rented the house; and living in Hattimuda for less than 12 months and households with latrine under construction in the study period were excluded from the study.

\section{Operational definitions}

Functional latrine was defined as the latrine with walls over $1.5 \mathrm{~ms}$, some type of closure over the entry, unbroken and unblocked pan and a functional pan-pipe-pit connection [20].

Latrine utilisation was defined as the use of the latrine by all the family members (above 5 years) in the households, that own private latrines.

Economic status of the family was categorized into below poverty line, which is per capita income less than 1.25 dollars per day per person and above poverty line, which is per capita income more than or equals to 1.25 dollars per day per person ( 1 US dollar $\approx 100$ Nepalese rupees) [21].

Occupation was classified according to Nepal Standard Occupations Classification-99 [22].

Houses were categorized into 3 types: Pucca with the floor, walls and roof all cemented, semi-pucca in which any one of the floors, walls, or roof is cemented and kuccha where none of the floor, walls and roof is cemented.

\section{Statistical analysis}

We entered the data into MS-Excel 2007 software followed by the Statistical Package for Social Sciences (version 17) for data analysis. Dependent variable was the utilisation of latrine among those with age above 5 years. Independent variables in the study included, the sociodemographic variables and the latrine related variables (age of the head of the household, education, family size, family type, house type, child under 5 years of age, economic status, distance of latrine from the kitchen, type of latrine, years of latrine construction, frequency of latrine cleaning, functionality of latrine, need of maintenance, reason for latrine construction, and the frequency of cleaning latrine).

The coverage and utilisation of latrine was expressed using descriptive data analysis. The Chi square test was performed to determine the association of utilisation of latrine with the independent variables. A $p$ value of $<0.05$ was considered as the cut-off point for statistical significance. Variables with p value $<0.20$ were further analyzed with multiple logistic regression to find out the strength of association between the variables.

\section{Results}

We approached 625 households were approached for the study. Two households did not agree to participate and 623 households were included in this study. The overall response rate was $99.7 \%$.

\section{Characteristics of the households}

Most of the respondents (57.6\%) were female. The mean age of the respondents was $36.1 \pm 40.3$ years and ranged from 16 to 84 years. Table 1 displays the socio-demographic characteristics of the 623 households. Among 623 households, 473 (75.9\%) had latrine at home. Those who did not have a latrine, the informants reported that all members of the household practice open defecation.

\section{Latrine utilisation and reasons for latrine construction}

Latrine utilized by all members above 5 years was $94.3 \%$. Self-initiation was the reason for the construction of latrine for $67.4 \%$ of the households while $16.5 \%$ credited advice from the health workers (Table 2).

\section{Characteristics of the latrines}

Most of the latrines (93.2\%) were pour flush type and the rest were of direct pit type. About $75.7 \%$ of latrines were at the distance of less than $6 \mathrm{~m}$ away from the kitchen. Among those households with latrines, 225 (47.6\%) latrines were constructed within last 2-year period. About $65.3 \%$ households with latrines, always clean their latrine after defecation. Half (50.1\%) of the respondents reported that Government or Non-Governmental Organization (NGO) helped them in some ways to construct their latrines. There were $89.4 \%$ of the latrines with wall over $1.5 \mathrm{~ms}$ and closure for privacy, which was also functional among 473 latrines. We found that there were $32.3 \%$ latrines for need of maintenance (Table 2).

\section{Factors associated with the use of latrine in Hattimuda}

Utilisation of latrines was less (OR 0.26, 95\% CI 0.11$0.62)$ in the households with child below 5 years. Latrines constructed within 2 years (OR $0.18,95 \%$ CI $0.07-0.51$ ), 
Table 1 Characteristics of the households in Hattimuda village $(n=623)$

\begin{tabular}{|c|c|c|c|}
\hline $\begin{array}{l}\text { Socio-demographic } \\
\text { characteristics }\end{array}$ & Categories & $\begin{array}{l}\text { Number } \\
\text { (n) }\end{array}$ & $\begin{array}{l}\text { Percentage } \\
\text { (\%) }\end{array}$ \\
\hline \multirow{2}{*}{$\begin{array}{l}\text { Gender of the inform- } \\
\text { ants }\end{array}$} & Male & 264 & 42.4 \\
\hline & Female & 359 & 57.6 \\
\hline \multirow{3}{*}{$\begin{array}{l}\text { Age of informant (in } \\
\text { years) }\end{array}$} & $<30$ & 215 & 34.5 \\
\hline & $30-49$ & 287 & 46.1 \\
\hline & $>50$ & 121 & 19.4 \\
\hline \multirow{3}{*}{$\begin{array}{l}\text { Age of the head of } \\
\text { household (in years) }\end{array}$} & $<30$ & 45 & 7.2 \\
\hline & $30-49$ & 356 & 57.1 \\
\hline & $>50$ & 222 & 35.6 \\
\hline \multirow[t]{2}{*}{ Religion } & Hindu & 476 & 76.4 \\
\hline & Others & 147 & 23.6 \\
\hline \multirow[t]{2}{*}{ Family size } & $\leq 5$ & 339 & 54.4 \\
\hline & $>5$ & 284 & 45.6 \\
\hline \multirow[t]{2}{*}{ Family type } & Nuclear & 407 & 65.3 \\
\hline & Joint & 216 & 34.7 \\
\hline \multirow{2}{*}{$\begin{array}{l}\text { Under } 5 \text { year child in } \\
\text { family }\end{array}$} & Present & 256 & 41.1 \\
\hline & Absent & 367 & 58.9 \\
\hline \multirow[t]{3}{*}{ House type } & Kuccha & 288 & 46.2 \\
\hline & Semi-pucca & 231 & 37.1 \\
\hline & Pucca & 104 & 16.7 \\
\hline \multirow{2}{*}{$\begin{array}{l}\text { Education of the head } \\
\text { of the household }\end{array}$} & Illiterate & 322 & 51.7 \\
\hline & Literate & 301 & 48.3 \\
\hline \multirow[t]{2}{*}{ Economic status } & Below poverty line & 476 & 76.4 \\
\hline & Above poverty line & 147 & 23.6 \\
\hline \multirow{2}{*}{$\begin{array}{l}\text { Presence of latrine at } \\
\text { home }\end{array}$} & Present & 473 & 75.9 \\
\hline & Absent & 150 & 24.1 \\
\hline
\end{tabular}

latrines needing maintenance (OR 0.21, 95\% CI 0.09$0.49)$ and latrines built with any assistance from government or NGO (OR 0.33, 95\% CI 0.13-0.80) were less likely to be utilised. Functional latrines (OR 18.81, 95\% CI 8.06-43.92), latrine height more than $1.5 \mathrm{~m}$ (OR 12.26, 95\% CI 5.35-28.07), latrines with closure for privacy (OR 21.97, 95\% CI 9.26-52.11) and latrines cleaned always (OR 3.45, 95\% CI 1.54-7.73) were more likely utilised.

The age of the head of the household, family size, family type, socioeconomic status, literacy status of the head of the household, type of latrine and distance of the latrine from the kitchen was not associated with the utilisation of the latrine in Hattimuda.

When the variables whose $\mathrm{p}$ value was taken as $<0.20$ were analysed on multivariate logistic regression, presence of child above 5 years, use of functional latrine, frequent cleaning of latrine and self-initiation of latrine construction were found to be significant factors for latrine utilisation.

The households having children less than 5 years were less likely to use latrine than those without child (AOR
Table 2 Latrine utilisation, reasons for construction and latrine characteristics in the households of Hattimuda village $(n=473)$

\begin{tabular}{|c|c|c|c|}
\hline Characteristics & Categories & Number (n) & Percentage (\%) \\
\hline \multirow[t]{2}{*}{ Utilisation of latrine } & Yes & 446 & 94.3 \\
\hline & No & 27 & 5.7 \\
\hline \multirow[t]{4}{*}{$\begin{array}{l}\text { Reasons for latrine } \\
\text { construction }\end{array}$} & $\begin{array}{l}\text { Advice from health } \\
\text { workers }\end{array}$ & 78 & 16.5 \\
\hline & Self-initiation & 319 & 67.4 \\
\hline & Peer pressure & 49 & 10.4 \\
\hline & $\begin{array}{l}\text { Imposition from } \\
\text { others }\end{array}$ & 27 & 5.7 \\
\hline \multirow[t]{2}{*}{ Type of latrine } & Direct pit & 32 & 6.8 \\
\hline & Pour flush & 441 & 93.2 \\
\hline \multirow{3}{*}{$\begin{array}{l}\text { Distance of latrine } \\
\text { from kitchen } \\
\text { (meter) }\end{array}$} & $<6$ & 358 & 75.7 \\
\hline & $6-10$ & 90 & 19.0 \\
\hline & $>10$ & 25 & 5.3 \\
\hline \multirow{2}{*}{$\begin{array}{l}\text { Years since latrine } \\
\text { constructed }\end{array}$} & $<2$ & 225 & 47.6 \\
\hline & $\geq 2$ & 248 & 52.4 \\
\hline \multirow[t]{3}{*}{ Latrine cleaning } & Always & 309 & 65.3 \\
\hline & Often & 101 & 21.4 \\
\hline & Rarely & 63 & 13.3 \\
\hline \multirow{2}{*}{$\begin{array}{l}\text { Assistance from } \\
\text { government/ } \\
\text { NGO to build } \\
\text { latrine }\end{array}$} & Yes & 237 & 50.1 \\
\hline & No & 236 & 49.9 \\
\hline \multirow{2}{*}{$\begin{array}{l}\text { Wall height over } \\
1.5 \mathrm{~m}\end{array}$} & Yes & 423 & 89.4 \\
\hline & No & 50 & 10.6 \\
\hline \multirow[t]{2}{*}{ Closure for privacy } & Yes & 434 & 91.8 \\
\hline & No & 39 & 8.2 \\
\hline \multirow[t]{2}{*}{ Functional } & Yes & 425 & 89.9 \\
\hline & No & 48 & 10.1 \\
\hline \multirow{2}{*}{$\begin{array}{l}\text { Need for mainte- } \\
\text { nance }\end{array}$} & Yes & 153 & 32.3 \\
\hline & No & 320 & 67.6 \\
\hline
\end{tabular}

$0.15,95 \%$ CI $0.05-0.46)$. The households with functional latrines were 27.37 times more likely to utilise latrine than those without a functional latrine (AOR 27.37, 95\% CI 6.85-109.45). People from households who always clean latrine were 3.66 times (AOR 3.66, 95\% CI 1.0912.29) more likely to utilise latrine than those who rarely clean latrine. The people from households who built latrine on self-initiation were 4.22 times more likely to use the latrine (AOR 4.21, 95\% CI 1.06-16.66) (Table 3).

\section{Discussion}

This study assessed the latrine coverage and its utilisation in a village of eastern Nepal. While the government of Nepal is committed to improve sanitation throughout the country, one priority campaign is improving latrine coverage towards attaining open defecation free areas all over the country by 2017 [17]. This community 
Table 3 Association of latrine utilisation with socio-demographic variables and latrine characteristics-multiple logistic regression analyses $(n=473)$

\begin{tabular}{|c|c|c|c|c|c|c|}
\hline Characteristics & Number (\%) & Total & $\begin{array}{l}\text { Unadjusted OR } \\
(95 \% \mathrm{Cl})\end{array}$ & $p$ value & $\begin{array}{l}\text { AOR } \\
(95 \% \mathrm{Cl})\end{array}$ & $p$ value \\
\hline \multicolumn{7}{|l|}{ Socio-demographic variables } \\
\hline Age of head of the household $<50$ years & $280(94.6)$ & 293 & $1.15(0.52-2.55)$ & 0.714 & - & - \\
\hline Family size $\leq 5$ members & $240(94.9)$ & 253 & $1.25(0.57-2.73)$ & 0.567 & - & - \\
\hline Joint family & $171(95.0)$ & 180 & $0.08(0.35-1.83)$ & 0.603 & - & - \\
\hline Presence of under 5 children & $173(90.1)$ & 192 & $0.26(0.11-0.62)$ & $<0.001^{*}$ & $0.15(0.05-0.46)$ & $0.001^{*}$ \\
\hline Semi pucca housing & $276(95.8)$ & 288 & $0.49(0.22-1.07)$ & 0.071 & $1.33(0.444-4.02)$ & 0.605 \\
\hline Illiterate head of the household & $212(93.4)$ & 227 & $0.90(0.43-1.89)$ & 0.418 & - & - \\
\hline Economic status below poverty line & $330(93.8)$ & 352 & $0.64(0.23-1.74)$ & 0.386 & - & - \\
\hline \multicolumn{7}{|l|}{ Characteristics of latrine } \\
\hline Flush type latrine & $421(95.5)$ & 441 & $0.16(0.06-0.43)$ & $<0.001^{*}$ & $2.37(0.56-9.99)$ & 0.240 \\
\hline Duration of latrine construction $\geq 2$ years & $243(98.0)$ & 248 & $0.18(0.07-051)$ & $<0.001^{*}$ & $3.02(0.84-10.91)$ & 0.090 \\
\hline Distance of latrine from kitchen $<6 \mathrm{~m}$ & $337(94.8)$ & 358 & $0.88(0.34-2.24)$ & 0.794 & - & - \\
\hline Functional latrine & $414(92.8)$ & 425 & $18.81(8.06-43.92)$ & $<0.001^{*}$ & $27.37(6.84-109.45)$ & $<0.001^{*}$ \\
\hline Need for maintenance & $135(88.2)$ & 153 & $0.21(0.09-0.49)$ & $<0.001^{*}$ & $1.64(0.46-5.83)$ & 0.439 \\
\hline Height of latrine $>1.5 \mathrm{~m}$ & $410(96.9)$ & 423 & $12.26(5.35-28.07)$ & $<0.001^{*}$ & $-^{\mathrm{a}}$ & - \\
\hline Closure for privacy & $422(97.2)$ & 434 & $21.97(9.26-52.11)$ & $<0.001^{*}$ & $-^{a}$ & - \\
\hline Frequency of latrine cleaning as always & $299(96.8)$ & 309 & $3.45(1.54-7.73)$ & $<0.05^{*}$ & $3.66(1.09-12.29)$ & $0.036^{*}$ \\
\hline Help from Government/NGO & $217(91.6)$ & 237 & $0.33(0.13-0.80)$ & $<0.05^{*}$ & $0.72(0.22-2.87)$ & 0.727 \\
\hline Self initiation of latrine construction & $304(95.3)$ & 319 & $1.71(0.78-3.75)$ & 0.175 & $4.21(1.06-16.66)$ & $0.040^{*}$ \\
\hline
\end{tabular}

a Variables not entered in multiple logistic regression since these variables represents functionality of latrine

* Statistically significant

based cross-sectional study provides evidence that while the coverage is improving utilisation of the constructed latrines may also need to improve through appropriate community based approaches. Among the 623 selected households, 75.9\% households possessed latrine. While $24.1 \%$ households who did not possess latrine, practiced open field defecation, and $5.7 \%$ of those having latrine at home still practiced open field defecation. A study from Bhopal, India also report similar proportion of people practicing open field defecation [23]. The latrine coverage of Hattimuda (75.9\%) from this study is higher than the national data (72.1\%), latrine coverage of Morang district (32.6\% as of 2015 [24]. According to the National Census data of 2011, the latrine coverage of Hattimuda was $38.9 \%$ and the National Coverage was 61.9\% [16]. Aiming for attaining the open defecation free status by 2017 [19], the coverage of latrine in Hattimuda has increased. The sanitary awareness and support campaigns implemented by the local government itself and the non-governmental organizations in the recent years to make the village open defecation free area are ongoing in Hattimuda [18, 25]. The impact of these individual programs on sanitation situation of the village is not available. As we purposively selected Hattimuda village closer to the community hospital, there may seem a space to question the generalisability of the results to other villages in Nepal. However, the socio-economic status, population density, living characteristics are similar to the other nearby villages [16]. However, we did not find other literatures regarding utilisation of the latrine; we believe that this study could still be used as evidence from rural Nepal. As Hattimuda village is nearer to the community hospital, the people may be more aware about the health consequences of not having a latrine and poor sanitation. The village nearer to the hospitals are expected have more access to health education and awareness campaigns. Assuming this, if the village closer to the hospitals are not fully utilising the latrines, means that the other villages will need more attention. However, we selected the village, also with the purpose of conducting follow up health promotion activities through the hospital.

Around $95 \%$ of household utilised the latrine in this study while it was reported to be $84 \%$ in rural Ethiopia [9], 38\% in rural India [20] and $8.8 \%$ in a study from Ethiopia [9]. A study from Uganda, reports of children not utilising the latrine despite its availability [26]. This could be due to possible differences in toilet behaviour practices among children from our settings.

In this study, there was no association between the age of the head of the household and latrine utilisation. This finding is in accordance with the studies done in Tanzania [27]. We found no significant association with the 
socioeconomic status of the people of Hattimuda and latrine utilisation. Nevertheless, some studies have shown a significant relationship between income and latrine utilisation [28].

The households with a child less than 5 years were associated with under utilisation of latrine in the present study, which is similar to the study done in Ethiopia [9]. The reason may be children less than 5 years cannot use the latrine properly so they practice open field defecation and those members accompanying these children could have practiced open field defecation.

Utilisation of the latrine was higher in households who took their own initiative to construct their latrine. This is accordance with findings from Ethiopia [8]. As people learn to accept, adopt and utilise latrine facilities easily by perceiving on their own and observing model latrine facilities than mere advice and enforcement. In contrast, utilisation of latrine was lower among households who constructed latrines with subsidy from Government/ Non-Government Organisation (NGO). Possible reason for lesser frequency of latrine use could be the low sense of ownership of the latrine in the household where latrine was not constructed based on the felt need of the family. The use was also lower in the households that had no financial contribution to their latrine construction.

Our study did not find an association between the duration of owning the latrine and its utilisation. This was found significant in the unadjusted model, which was not significant later in the adjusted model. Studies from Ethiopia [29] and India [20] however found an association. This may be due to the behavioural patterns that may be different from the countries that could influence latrine utilisation in Hattimuda, which may require further exploration.

In our study, we found an association of latrine utilisation with the type of latrine, which is similar to the study done in Tanzania [27]. Flush latrines are more likely to be utilised than the pit latrines. The probable reason may be fear of odour and nuisance created by houseflies linked with traditional pit latrines.

The utilisation of latrines depended on their functionality and need of maintenance in Hattimuda as also reported in Ethiopia [8]. Non-functional latrine gives various problems such as leakage, privacy issues, lack of comfort that may hinder its use. Similarly, presence of door and height of latrine above $1.5 \mathrm{~m}$ was positively associated with latrine utilisation. These findings are similar to the study done in India and Ethiopia [20,29].

The frequency of cleaning of the latrine was associated with the utilisation of latrine in this study. This is analogous to the study done in Ethiopia [9]. Households who clean their latrine more frequently were more likely to utilise their latrine than those who clean their latrine less frequently. This is consistent with other studies which concluded that foul odour is a determinant for latrine non-utilisation $[29,30]$.

\section{Limitations of the study}

As this a cross-sectional study, we could only find the association between the factors and the latrine utilisation, the causality could not be established. The purposive selection of the study site closer to the hospital could have influenced the responses by the respondents.

\section{Conclusions}

Latrine coverage in the Hattimuda village is improving. Utilisation of the latrine was better in households, when the latrine was functional, cleaned regularly, built by selfinitiation, and with the presence of a child under 5 years. The factors identified may be useful for practitioners working for open defecation free initiative in Nepal to promote latrine utilisation. Interventions focusing on motivating the building of latrines at households could improve the utilisation. There is a need to identify locally appropriate interventions to improve latrine coverage and utilisation in the local context.

\section{Additional file}

Additional file 1. Table showing sample size in randomly selected wards in Hattimuda VDC, Morang District, Nepal.

\section{Abbreviations \\ AOR: adjusted odds ratio; Cl: confidence interval; NGO: Non-Government Organisation; ODF: open defecation free; OR: odds ratio.}

\section{Authors' contributions}

SSB, GS, MB \& PKP conceived the study. SSB, GS, MB, SBS, NJ \& PKP all contributed to the design of the study. Literature review was done by SSB, GS \& PKP. Data collection and analysis was done by SSB, GS \& MB. Preliminary report writing was performed by SSB, GS, MB \& SBS. Manuscript editing and review was done by SSB, GS, NJ \& PKP. All authors read and approved the final manuscript.

\section{Acknowledgements \\ We are heartily thankful to (Mohsin Hassan, Munna Keshari, Naresh Kafle. Navin Bhatt, Nikhil Agarwal, Niraj Paudel, Nivesh Yadav, Puja Rauniyar, Rubina Maharjan and Sajana Poudel) EPIDMAN Group V, MBBS students Batch 2012 of B P Koirala Institute of Health Sciences, Dharan, Nepal. We are also thankful to the residents of Hattimuda village, who participated in the study.}

\section{Competing interests}

The authors declare that they have no competing interests.

\section{Availability of data and materials}

All data generated or analysed during this study are included in this published article.

\section{Ethics and consent to participate}

The approval for this study was taken from the Institutional Review Committee of the B P Koirala Institute of Health Sciences, Dharan, Nepal. Data collection was done after obtaining informed written consents from the participants and confidentiality was maintained. 


\section{Publisher's Note}

Springer Nature remains neutral with regard to jurisdictional claims in published maps and institutional affiliations.

Received: 29 February 2016 Accepted: 8 June 2017

Published online: 12 June 2017

\section{References}

1. World Health Organization. Sanitation. Fact Sheet No 392. 2015. http:// www.who.int/mediacentre/factsheets/fs392/en/. Accessed 19 Dec 2015.

2. Pruss A, Kay D, Fewtrell L, Bartram J. Estimating the burden of disease from water, sanitation, and hygiene at a global level. Environ Health Perspect. 2002;110(5):537-42

3. Lozano R, Naghavi M, Foreman K, Lim S, Shibuya K, Aboyans V, et al. Global and regional mortality from 235 causes of death for 20 age groups in 1990 and 2010: a systematic analysis for the Global Burden of Disease Study 2010. Lancet. 2012;380(9859):2095-128.

4. United Nations Children's Fund, World Health Organization. Progress on drinking-water and sanitation-2012 Update. New York; 2012

5. Lantagne DS, Gallo W. Safe water for the community: a guide for establishing a community-based safe water system program. Atlanta; 2008.

6. Courtright P, Sheppard J, Lane S, Sadek A, Schachter J, Dawson CR. Latrine ownership as a protective factor in inflammatory trachoma in Egypt. Br J Ophthalmol. 1991;75(6):322-5.

7. Rabiu M, Alhassan MB, Ejere HO. Environmental sanitary interventions for preventing active trachoma. Cochrane Database Syst Rev. 2007:4:CD004003.

8. Gedefaw M, Amsalu Y, Tarekegn M, Awoke W. Opportunities, and challenges of latrine utilization among rural communities of Awabel District, Northwest Ethiopia, 2014. Open J Epidemiol. 2015:5(May):98-106.

9. Yimam YT, Gelaye KA, Chercos DH. Latrine utilization and associated factors among people living in rural areas of Denbia District, Northwest Ethiopia, 2013, a cross-sectional study. Pan Afr Med J. 2014;18:1-10.

10. Smith RS. Sanitation: controlling problems at source. WHO: water, sanitation and health. 2015. p. 1-11. Available from: www.who.int/water_sanitation_health/sanitproblems/en/print.html. Accessed 01 Dec 2015.

11. Dumba R, Kaddu JB, Mangen FW. Intestinal helminths in Luweero district, Uganda. Afr Health Sci. 2008;8(2):90-6.

12. United Nations Children's Fund (UNICEF). Water, sanitation and hygiene annual report 2013. New York; 2014.

13. Budhathoki SS, Bhattachan M, Yadav AK, Upadhyaya P, Pokharel PK. Ecosocial and behavioural determinants of diarrhoea in under five children of Nepal: a framework analysis of the existing literature. Trop Med Health. 2016;44:7.

14. Ministry of Health and Population (MOHP) Nepal. Nepal demographic and health survey 2011. Kathmandu; 2012.
15. Azage M, Haile D. Factors associated with safe child feces disposal practices in Ethiopia: evidence from demographic and health survey. Arch Public Health. 2015;73(1):40.

16. Central Bureau of Statistics. National population and housing census 2011, vol. 1. Kathmandu; 2012.

17. Government of Nepal. Sanitation and hygiene master plan. Kathmandu; 2011

18. UNICEF. Big steps towards an open-defecation-free Nepal. 2013. http:// www.unicef.org/infobycountry/nepal 70745.html. Accessed 02 Oct 2015.

19. Office of the Hattimuda Village Development Committee. Hattimuda Village Development Committee Annual Report 2071-2072. Hattimuda; 2015.

20. Barnard S, Routray P, Majorin F, Peletz R, Boisson S, Sinha A, et al. Impact of indian total sanitation campaign on latrine coverage and use: a cross sectional study in Orissa 3 years following programme implementation. PLOS ONE. 2013:8(8):e71438.

21. Ravallion $M$, Chen $S$, Sangroula P. Dollar a day revisited. The World Bank Economic Review; 2009.

22. Central Bureau of Statistics. Nepal standard classification of occupationNSCO-99. Kathmandu; 1999.

23. Biran A, Jenkins MW, Dabrase P, Bhagwat I. Patterns and determinants of communal latrine usage in urban poverty pockets in Bhopal, India. Trop Med Int Health. 2011;16(7):854-62.

24. National Sanitation and Hygiene Coordination Committee's Secretariat Government of Nepal. ODF data by coverage environmental sanitation section. 2016. http://www.ess.gov.np/ne/kabharej. Accessed 29 Dec 2016

25. Nepal WASH Alliance. Open defecation free (ODF) status updates in Nepal. Water, Sanitation and hygiene resource centre network Nepal. 2016. http://www.wash-rcnn.net.np/nwa/odf-updates.html. Accessed 28 Jan 2016.

26. Nansereko F. Adequacy and utilisation of sanitation facilities in secondary school in Mpigi District. Makerere University; 2010.

27. Kema K, Semali I, Mkuwa S, Kagonji I, Temu F, Ilako F, et al. Factors affecting the utilisation of improved ventilated latrines among communities in Mtwara Rural District, Tanzania. Pan Afr Med J. 2012;13(Suppl 1):4.

28. Debesay N, Ingale L, Gebresilassie A, Assefa H, Yemane D. Latrine utilization and associated factors in the rural communities of Gulomekada District, Tigray Region, North Ethiopia, 2013: a community based crosssectional study. J Commun Med Health Educ. 2015:5(2):338

29. Anteneh A, Kumie A. Assessment of the impact of latrine utilization on diarrhoeal diseases in the rural community of Hulet Ejju Enessie Woreda, East Gojjam Zone, Amhara Region. Ethiop J Health Dev. 2010;24(2):110-8.

30. Obeng PA, Keraita B, Oduro-Kwarteng S, Bregnhøj H, Abaidoo RC, Awuah E, et al. Usage and a Ghanaian peri-community. Environ Process. 2015:2(1):261-74

\section{Submit your next manuscript to BioMed Central} and we will help you at every step:

- We accept pre-submission inquiries

- Our selector tool helps you to find the most relevant journal

- We provide round the clock customer support

- Convenient online submission

- Thorough peer review

- Inclusion in PubMed and all major indexing services

- Maximum visibility for your research

Submit your manuscript at www.biomedcentral com/submit
C Biomed Central 